\title{
COSMETICS USAGE HABITS AND RELATED SIDE EFFECTS AMONG FEMALES: LITHUANIAN CASE \\ Gražina Šniepiené $\dot{1}^{1,3}$, Judita Jonuševičiené $\dot{2}^{2}$
}

\begin{abstract}
:
Background. Nowadays, it is generally recognized that physical appearance is important, women are particularly interested in their aesthetic appearance and the use of various cosmetic products. The long-term usage habits of cosmetic products have influenced not only the condition of the skin and hair but also on human health.

The aim of the survey was to investigate cosmetics use habits and related side effects among females.

Methods: A quantitative survey was performed; an original questionnaire based on scientific resources was used, used data collection method - a written survey. Survey sample - 336 Lithuanian women. Data analysis was performed using the social research statistics program SPSS 25.0. Percentage frequencies were calculated for ordinal variables - averages and standard deviations. The Pearson's Chi-Square test and the non-parametric Kruskal Wallis and Mann Whitney tests were used to detect statistically significant differences. The significance level selected was $\mathrm{p}<0.05$.

Results. The survey revealed the prevalence and frequency of the use of cosmetic products by women, as well as the choice criteria for selecting cosmetic products. The side effects related to the use of cosmetics experienced by women are investigated as well as some practices and habits regarding the use of cosmetics.

Conclusions. The study shows that the choice criteria of cosmetic products differ among separate women age groups. The older women are more concerned about the composition of the products, their naturalness, and the manufacturer, while the price is less important. Most commonly used are personal hygiene products including deodorants and perfumers. The older women use less cosmetic products $(\mathrm{p}<0.05)$ than the younger ones. The majority of women have experienced side effects related to the use of cosmetics. The study shows that the occurrence of side effects does not depend on the number of products used. However, they are related to the use habits: women who experience side effects more often $(p<0.05)$ use expired cosmetic products. In addition, women with side effects are less likely to use cosmetic testers.
\end{abstract}

UDC Classification: 646.7, DOI: 10.12955/cbup.v7.1462

Keywords: Cosmetics, Usage Habits, Side Effects, Females.

\section{Introduction}

Nowadays, when it is generally recognized that physical appearance is important, cosmetic products are used worldwide (Bernard, 2016; Dornic et al, 2017; Ahaiwe et al, 2015; Onyedikachi, 2016). The beauty industry has a lot of influence on a women's life: retouched photos in magazines, women without makeup make them feel ugly, thus promoting the use of cosmetics (Massoro, 2016; Cho et al., 2017). The use of cosmetics is associated with a variety of social outcomes, ranging from perception of physical attractiveness to evaluation of expected job performance (Bartles, 2019).

However, in many countries, as well as in Lithuania, there is anxiety about the impact of cosmetic products on consumer health in the society (Malinauskiené, 2015; Cho et al., 2017; Kirchhof \& Gannes, 2013; Yamaguchi et al., 2017).

Lithuania is not among the leaders of cosmetic countries, producing and dominating in the export of products to other countries of the world, but it has a lot of small manufacturers of cosmetics. In addition, cosmetic products are imported from many countries. The women of Lithuania use a lot of cosmetic products (Vainauskiene and Vaitkiene, 2014). At present, the cosmetics market in Lithuania and throughout the European Union is regulated at a "European level" and the Reglament (Commission, E., 2009 ) is one of the main regulatory document. Increasing competition in all European countries encourages manufacturers to ensure the safety and quality of cosmetics. However, in Lithuania, as well as in some other countries sometimes there is a lack of strict regulations (Malinauskiene et al., 2015).

Cosmetics contain a variety of chemical substances that can enter the body through inhalation, dermal contact, or ingestion (Park, 2015). In addition to the active substances, some additives such as preservatives, stabilizers, mineral pigments, dyes, and fragrance are used in cosmetic products. Some of these substances may have harmful effects on human health, ranging from acute symptoms such as irritation to chronic diseases (Marsh et al., 2017, Massoro, 2016; Park, 2015; Zirwas, 2019; Dornic et al., 2017; Kim et al., 2016; Giulivo et al., 2016; Jurewicz et al., 2017; Zhaoa et al., 2018; Nowaka et al., 2018).

\footnotetext{
${ }^{1}$ Klaipeda State University of Applied Sciences, Faculty of Health Science, Lithuania, g.sniepiene @ kvk.lt

${ }^{2}$ Klaipeda State University of Applied Sciences, Business Faculty, Lithuania, j.jonuseviciene@kvk.lt

${ }^{3}$ Klaipeda University, Faculty of Health Sciences, Department of Nursing, Lithuania.
} 
The public is concerned about substances with endocrine disrupting potential and reproductive toxicity that are widely used in cosmetic products, especially their effects on human embryos, newborns and children. With the help of modern technologies, parabens and UV filters are detected in human placenta tissues and breast milk (Vela-Soriaa et al., 2017, Fotouhi et al., 2017; Jurewicz et al., 2017; Geer et al., 2017). This is worrying that these substances interfere with the development of the foetus.

However, sometimes people are worried unreasonably about personal care and cosmetic products, reflecting the controversy and media scare generated over the harmful effect of cosmetics (Cho et al., 2017).

Sometimes research on the toxic effects of cosmetics is misinterpreted. Therefore, the perception that all personal care products and cosmetics pose a threat to human health is not scientifically supported, and claims made to the contrary should be regarded as false and misleading (Bondi et al., 2015). Some authors report the safety of some ingredients in cosmetics (Kirchhof and Gannes, 2013). Some environmental studies show safe concentrations of chemicals in the environment causing no hazards to human health (Lu et al., 2019).

As society focuses more and more on youthfulness and beauty, cosmetics in some forms are used daily and abundantly almost by everyone. It can lead to a higher chance of developing allergic or irritant contact dermatitis. The concern is caused by the age of females who begin using cosmetics and wearing makeup become younger and younger with every new generation (Shrestha and Shakya, 2016; Cho et al., 2017). The studies reveal that young females have no experience in the safe use of cosmetics and the majority of them have insufficient knowledge (Shrestha and Shakya, 2016; Nayak et al., 2017; Kim et al., 2016; Masssoro, 2016). Surveys of cosmetic consumers show that females often rely on the controversy and media scare generated over cosmetics (Cho et al., 2017).

The use habits of cosmetic products also affects the health of consumers. The occurrence of adverse reactions depends on the sensitivity of the person and sometimes on inappropriate use (Wu \& Lee, 2016; Cho et al., 2017). Women try to solve their skin aesthetic problems with the use of more cosmetic products, but more attention should be paid to choosing the right ones (Nayak et al., 2017).

The consumers should choose cosmetic products which are favourable to their health and develop appropriate habits and practices in the consumption of cosmetic and personal care products (Comiskey et al., 2015; Kim et al., 2016; Bernard et al., 2016; Ficheux et al., 2015; Dornic et al., 2016; Ficheux et al., 2016; Shrestha and Shakya, 2016). The effects of cosmetic products, as well as the occurrence or absence of adverse reactions often depend on their use habits.

The aim of the study is to investigate cosmetics use habits and related side effects among females.

\section{Data and methodology}

Data was collected using an online survey on social networks (closed groups of female users) and direct communication with women. The survey was conducted in 2018. The research instrument: an original questionnaire created by the study authors and based on existing scientific research; was compromised of 25 questions, 4 open choice and 21 multiple choice. The questionnaire consisted of the following parts: demographic questions (age and place of residence); cosmetic product selection criteria; frequency of use of cosmetic products and questions about undesirable side effects of cosmetic products. The questionnaire was designed to evaluate the frequency of use of cosmetic products and the undesirable side effects. Cosmetic products are divided into 5 groups: hygiene and body care, skin care, hair care, decorative cosmetics and tanning products. A frequency scale was used where 1 is 1 time or less per month, 2-1-2 times a week, 3-3-4 times a week, 4-5-6 times a week, 5-1 time a day 6-2 and more times a day and $0-$ do not use. Cronbach's alpha coefficient was calculated for the internal reliability of the questionnaire. Cronbach alpha values for all ordinal variables were greater than 0.8 , which indicates good reliability of the questionnaire.

Data analysis was performed using the social research statistics program SPSS 25.0. Percentage frequencies were calculated for ordinal variables - averages and standard deviations. A Pearson's Chi Square test and the non-parametric Kruskal Wallis and Mann Whitney tests were used to detect statistically significant differences. The significance level selected was $\mathrm{p}<0.05$. Correlation analysis was performed; the Spearman correlation coefficient was calculated for the ordinal variables to determine statistically significant relationships between the frequency and age of cosmetic use and the frequency of use and the number of products used. The survey sample consisted of 336 Lithuanian 
women, of which a majority were from Lithuanian cities - 68.1\%, and the rest from towns and villages $-31.8 \%$. The distribution of respondents by age is as follows: $16-25$ years old. - 46.2\%, 26-40 years old - $38.2 \%$ and older than $41-15.6 \%$. During the research, ethical principles were followed.

\section{Results}

Cosmetics use habits of the respondents. When evaluating the criteria for choosing the cosmetic products of the women participating in the study, it was found that the most important criteria was product effectiveness $(\mathrm{M}=4.6, \mathrm{SD}=0.60)$, as well as the "available" product price $(\mathrm{M}=4.08, \mathrm{SD}=$ $0.86)$ and product ingredient list $(\mathrm{M}=4.07, \mathrm{SD}=0.94)$. For more than half of the respondents, it is important that the selected product were tested (used previously, $\mathrm{M}=4.02, \mathrm{SD}=0.92$ ) ingredients are natural $(\mathrm{M}=3.9, \mathrm{SD}=0.97)$, the smell of the product was also important $(\mathrm{M}=3.74, \mathrm{SD}=1.03)$ (Figure $1)$.

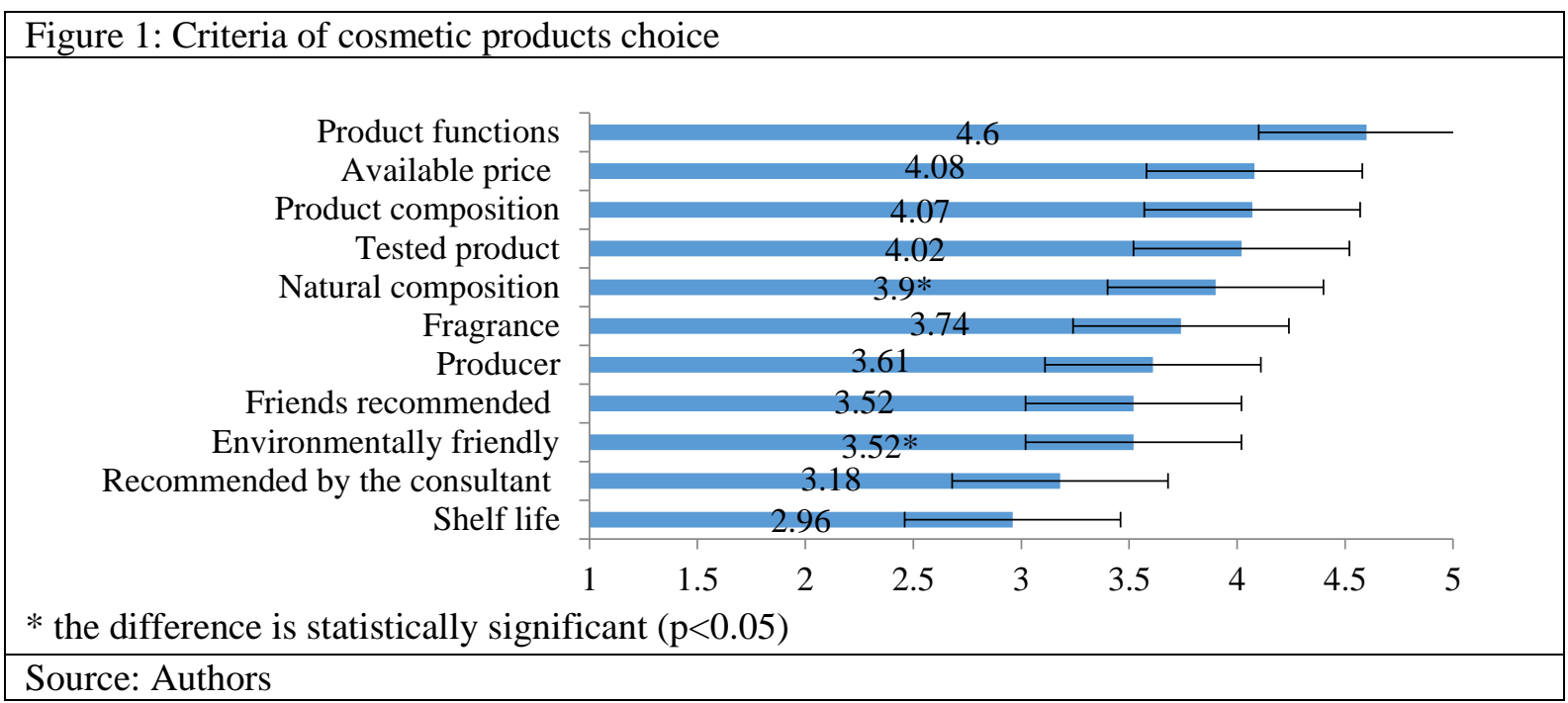

In assessing the frequency of use of personal hygiene, body and facial care products, it has been found that the most used is solid soap $(\mathrm{M}=5.57, \mathrm{SD}=1.09)$, toothpaste $(\mathrm{M}=5.55, \mathrm{SD}=1.07)$, deodorants, antiperspirants $(\mathrm{M}=4.97, \mathrm{SD})=1.10)$ and facial day cream $(\mathrm{M}=4.96, \mathrm{SD}=1.33)$. In summary, it can be said that women use these products daily. Perfumes and eau de toilette are also used frequently, almost daily $(\mathrm{M}=4.88, \mathrm{SD}=1.23)$. Statistically significant $(\mathrm{p}<0.05)$ women aged 41 and older use more eye oils and creams then younger respondents (Table 1 ).

\begin{tabular}{|c|c|c|c|c|c|c|c|}
\hline \multirow{2}{*}{$\begin{array}{l}\text { General hygiene and body } \\
\text { products }\end{array}$} & \multicolumn{3}{|c|}{ Characteristics } & \multirow{2}{*}{ Face products } & \multicolumn{3}{|c|}{ Characteristics } \\
\hline & $\mathbf{N}$ & Mean & SD & & $\mathbf{N}$ & Mean & SD \\
\hline Toothpaste & 336 & 5.55 & 1.065 & Cleansing milk & 261 & 4.46 & 1.575 \\
\hline Mouthwash & 195 & 3,99 & 1.786 & Cleansing wipes & 159 & 2.54 & 1.215 \\
\hline Solid soap & 276 & 5.57 & 1.088 & Lotion/tonic & 215 & 4.22 & 1.692 \\
\hline Shower gel & 305 & 4.53 & 1.253 & Facial exfoliating scrub & 242 & 2.36 & 1.159 \\
\hline Exfoliating scrub & 244 & 2.01 & 0.921 & Day cream & 302 & 4.96 & 1.331 \\
\hline Body lotion & 265 & 3.28 & 1.530 & Facial oil & 97 & $2.47 *$ & 1.608 \\
\hline Intimate hygiene & 216 & 4.50 & 1.494 & Eye contour & 134 & $3.92 *$ & 1.970 \\
\hline Deodorant/antiperspirant & 293 & 4.97 & 1.101 & Facial mask & 251 & $1, .93$ & 0.896 \\
\hline Hand cream & 275 & 4.46 & 1.619 & Serum & 124 & 3.06 & 1.710 \\
\hline Feet cream & 201 & 3.25 & 1.643 & Massage gel/cream & 52 & 2.06 & 1.602 \\
\hline Depilatory & 135 & 1.85 & 1.325 & Ampoule cosmetics & 60 & 1.80 & 1.388 \\
\hline Perfume/eau de toilette & 289 & 4.88 & 1,225 & Night cream & 295 & 4.52 & 0.992 \\
\hline Nail polish & 106 & 1.99 & 1.132 & Lip balm & 121 & 3.26 & 1.522 \\
\hline
\end{tabular}

Assessing the criteria for selecting cosmetic products by age group of respondents (Kruskal Vallis nonparametric test), statistically significantly more ( $p$ <.05) older (from 41 years old) women look at the 
ingredient list and prefers natural and environmentally friendly products. There were no statistically significant differences in the relationship between product choice and the occurrence of side effects (Mann Whitney test applied), the occurrence of side effects does not depend on the selection criteria. Most women purchase beauty products in specialized cosmetics stores $(80.1 \%)$, supermarkets $(32.6 \%)$ and pharmacies (35.9\%), and a significant proportion of respondents say they buy them online (30.6\%). More than a third of women use between 5 and 10 products daily (38.5\%), a similar percentage indicates that they use between 1 and 5 products daily (30.2\%), 14.6\% women uses more than 15 products a day. Analysing hair care product usage frequency it has been found that shampoo $(\mathrm{M}=3.25, \mathrm{SD}=1.04)$ and conditioner $(\mathrm{M}=3.01, \mathrm{SD}=1.13)$ are commonly used 3-4 times a week, less frequently used are hair dyes $(\mathrm{M}=1.06, \mathrm{SD}=0.45)$. From decorative cosmetics, it was statistically significantly seen that eyelash mascara $(\mathrm{M}=3.86, \mathrm{SD}=1.49)$ are most commonly used, while lipstick and eye shadow are used by women in the age group 41 years and older $(\mathrm{p}<0.05)$ (Table 2).

\begin{tabular}{|c|c|c|c|c|c|c|c|}
\hline \multirow[b]{2}{*}{ Hair care } & \multicolumn{3}{|c|}{ Characteristics } & \multirow[b]{2}{*}{ Makeup products } & \multicolumn{3}{|c|}{ Characteristics } \\
\hline & $\mathbf{N}$ & Mean & SD & & $\mathbf{N}$ & Mean & SD \\
\hline Shampoo & 301 & 3.25 & 1.039 & Cream foundation & 257 & 3.30 & 1.622 \\
\hline Hair mask & 258 & 2.31 & 1.008 & $\begin{array}{l}\text { Compact/Loose powder } \\
\text { foundation }\end{array}$ & 186 & 3.04 & 1.702 \\
\hline Conditioner & 270 & 3.01 & 1.129 & Lipstick/lip gloss & 259 & $3.20^{*}$ & 1.802 \\
\hline Hair oil/serum & 225 & 2.95 & 1.265 & Rouge & 197 & 2.89 & 1.700 \\
\hline Hair wax & 66 & 1.97 & 1.519 & Eye shadow & 230 & $2.31 *$ & 1.569 \\
\hline Hairspray & 140 & 2.09 & 1.538 & Mascara & 279 & 3.83 & 1.490 \\
\hline Hair dye & 210 & 1.06 & 0.449 & Eye/Eyebrow/Lip pencil & 254 & 3.78 & 1.569 \\
\hline Styling Gel & 152 & 2.20 & 1.453 & Make-up remover & 242 & 3.56 & 1.421 \\
\hline
\end{tabular}

When assessing tanning product frequency of use, it was observed that tanning and sunscreen products are not used frequently. Sunscreens are most often used (UV filters) $(\mathrm{M}=1.99, \mathrm{SD}=1.56)$, but tanning and after sun products are used less (Figure 2).

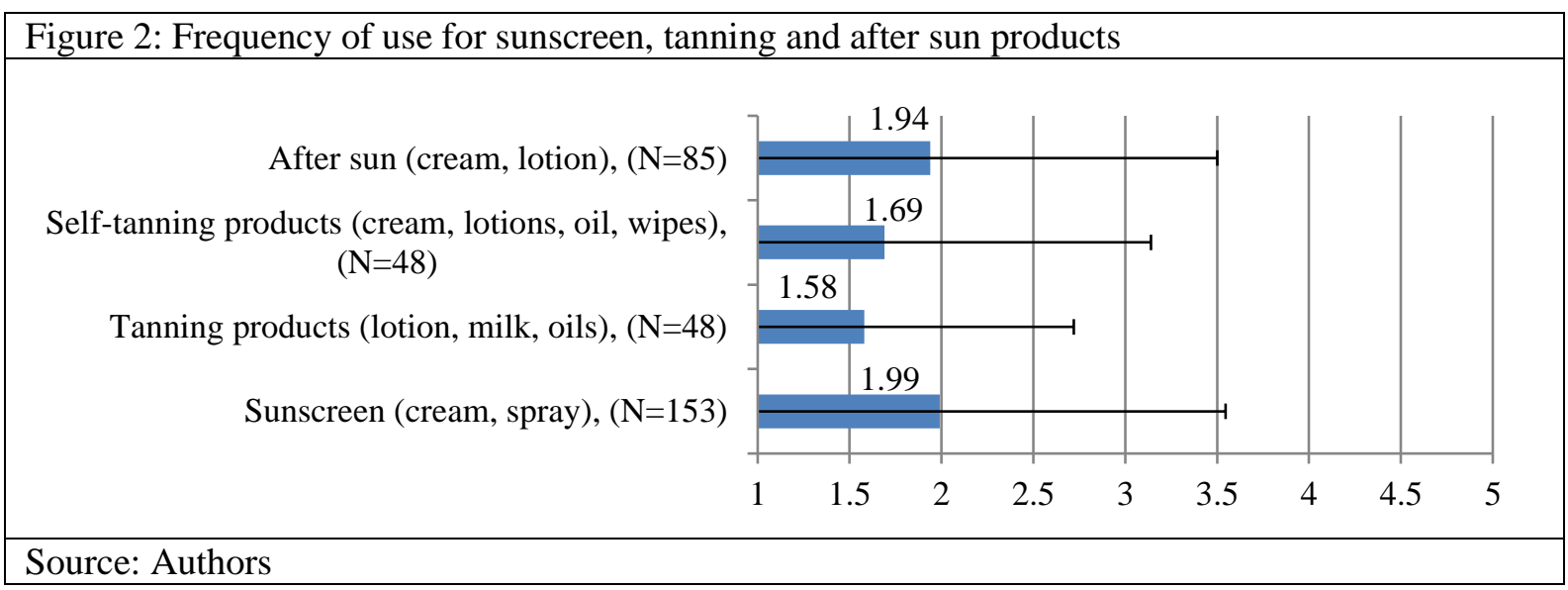

The relationship between the selection criteria of cosmetics, the frequency of use of the products, age of the women and the number of products used was determined by a statistically significant correlation between the selection criteria and age when choosing cosmetic products by ingredients $(r=0.168$, $p=0.01)$, choosing the most natural ingredients $(r=0.141, p<0.05)$ and by manufacturer $(r=0.114$, $\mathrm{p}<0.05)$. For older women product ingredients are very important, their naturalness and manufacturer, while the relationship between price and age is reversed $(r=-0.128, p<0.05)$, it can be said that older women take less into account the price of the cosmetics. It was found statistically significant that older women use more eye cream $(\mathrm{r}=0.341, \mathrm{p}<0.05)$, hair spray $(\mathrm{r}=0.217, \mathrm{p}<0.05)$, but less often use hair masks $(r=-0.182, p<0.05)$. The older the women, the more often they use lipstick $(r=0.295, p<0.05)$ and eye shadow $(r=0.176, p<0.05)$. Analysing tanning product usage frequency and consumer age, older women were more likely to use sunscreen products $(\mathrm{r}=0.298, \mathrm{p}<0.01)$. There was a statistically 
significant reversal correlation between the age range and the number of products used per day: as age increases, the number of products used per day decreases $(r=-0.194, \mathrm{p}<0.05)$.

Side effects related to the use of cosmetics. When evaluating the frequency of side effects experienced by respondents, it was found that $80.4 \%(\mathrm{n}=270)$ of respondents experienced side effects while using cosmetic products. Out of them 67.1 per cent $(\mathrm{n}=180)$ experienced skin irritation reactions and $57.1 \%$ $(\mathrm{n}=154)$ experienced eye irritation, redness, swelling of the eyelids. 19.6\% $(\mathrm{n}=66)$ of respondents experienced no side effects (Figure 3). 8.6\% of women who experienced various side effects contacted a physician. These included: allergic contact dermatitis, eczema, skin irritation and ocular inflammation. When evaluating the occurrence of side effects and the use of cosmetic products, it was found that women who experienced side effects were more likely to use perfumes, fragrances, deodorants or antiperspirants and make-up removers $(\mathrm{p}<0.05)$ (Table 3$)$.

\begin{tabular}{|r|r|r|r|r|}
\hline Figure 3: Reactions to cosmetics (side-effects) \\
$\begin{array}{r}\text { Unexperienced } \\
\text { Skin irritation, itching, burning, redness }\end{array}$ \\
$\begin{array}{r}\text { Rashes } \\
\text { Scaling }\end{array}$ \\
Eye tearing, redness, itching, oedema of the eye lids \\
Phototoxic, photoallergic reactions \\
Nasal iritaion \\
Exacerbation of asthma
\end{tabular}

\begin{tabular}{|c|c|c|c|c|c|}
\hline Products & Groups & $\begin{array}{l}\text { Mean } \\
\text { Rank }\end{array}$ & $\begin{array}{c}\text { Mann } \\
\text { Whitney }\end{array}$ & $\mathbf{Z}$ & $\mathbf{p}$ \\
\hline \multirow{2}{*}{ Deodorant/antiperspirant } & Experienced & 151.24 & \multirow{2}{*}{5725.5} & \multirow{2}{*}{-1.934} & \multirow{2}{*}{0.049} \\
\hline & Unexperienced & 129,45 & & & \\
\hline \multirow{2}{*}{ Perfume/eau de toilette } & Experienced & 156.28 & \multirow{2}{*}{6105.0} & \multirow{2}{*}{-0.579} & \multirow{2}{*}{0.048} \\
\hline & Unexperienced & 139.55 & & & \\
\hline \multirow{2}{*}{ Facial lotion/tonic } & Experienced & 104.79 & \multirow{2}{*}{2867.0} & \multirow{2}{*}{-1.116} & \multirow{2}{*}{0.045} \\
\hline & Unexperienced & 122.49 & & & \\
\hline \multirow{2}{*}{ Make-up remover } & Experienced & 135.77 & \multirow{2}{*}{4737.0} & \multirow{2}{*}{-1.137} & \multirow{2}{*}{0.049} \\
\hline & Unexperienced & 123.19 & & & \\
\hline
\end{tabular}

\begin{tabular}{|c|c|c|c|c|c|}
\hline \multirow[b]{2}{*}{ Criterion } & \multicolumn{2}{|c|}{ Groups } & \multirow{2}{*}{$\begin{array}{l}\text { Pearson } \\
\text { Chi- } \\
\text { Square }\end{array}$} & \multirow[b]{2}{*}{ df } & \multirow[b]{2}{*}{$\mathbf{p}$} \\
\hline & Unxperienced & Experienced & & & \\
\hline $\begin{array}{l}\text { Read the composition of the product on } \\
\text { the label (Yes, No) }\end{array}$ & $59.9 \%$ & $40.1 \%$ & 1.603 & 2 & 0.433 \\
\hline Read the safety instructions (Yes, No) & $47.5 \%$ & $52.5 \%$ & 1.052 & 2 & 0.793 \\
\hline $\begin{array}{l}\text { Ask about the presence of hazard } \\
\text { ingredients (Yes, No) }\end{array}$ & $43.4 \%$ & $56.6 \%$ & 1.301 & 2 & 0.608 \\
\hline $\begin{array}{l}\text { Remember the expiry and manufacture } \\
\text { date (Yes, No) }\end{array}$ & $43.4 \%$ & $56.6 \%$ & 1.302 & 2 & 0.522 \\
\hline $\begin{array}{l}\text { Use cosmetic testers (occasionally, } \\
\text { frequently) }\end{array}$ & $83.8 \%$ & $16.2 \%$ & 5.232 & 1 & 0.049 \\
\hline Avoid certain ingredients (Yes, No) & $39.3 \%$ & $60.7 \%$ & 6.513 & 2 & $\mathbf{0 . 0 3 9}$ \\
\hline Use expired products (Yes, No) & $19.4 \%$ & $81.7 \%$ & 8.291 & 2 & 0.016 \\
\hline
\end{tabular}


When assessing the relationship between side effects and the age of the users the occurrence of undesirable effects was not age-dependent. The incidence of undesirable effects was also found to be independent of the number of products used. It was found that, women who experience side effects more often use expired cosmetic products $\left(\chi^{2}=8.291, \mathrm{p}=0.016\right)$. The study found that there is a significant difference when answering the question about choosing a cosmetic product without certain ingredients. Women with side effects $(\chi 2=6.513, \mathrm{p}=0.039)$ are more likely to agree with this statement. The study showed that women who had undesirable effects less frequently used product testers before buying products $\left(\chi^{2}=5.232, \mathrm{p}=0.049\right)$ (Table 4$)$.

The study showed that the most common side effects occurred when using the following cosmetic products: mascara, eye shadows, facial creams, and others (Table 5). More than a third (35.9\%) women noted avoiding some cosmetic ingredients: Sodium laureth sulfate (SLS), preservatives (especially parabens), aluminium salts, alcohols, mineral oils.

Table 5: Products that have caused side effects

\begin{tabular}{|l|l|c|}
\hline \multicolumn{1}{|c|}{ Product groups } & \multicolumn{1}{|c|}{ Products } & $\begin{array}{c}\text { Percent, number } \\
\text { of cases }\end{array}$ \\
\hline $\begin{array}{l}\text { Cosmetics (makeup } \\
\text { products) }\end{array}$ & $\begin{array}{l}\text { Mascara (30), Eye shadow (10), Cream foundation (19); Eye } \\
\text { pencil (5), Lipstick (1), Rouge (4), Make-up remover (4); }\end{array}$ & $47.1 \%(\mathrm{n}=73)$ \\
\hline Face products & Day/night cream (25), Mask (10), Lotion/tonic (3), Serum (1) & $26.4 \%(\mathrm{n}=41)$ \\
\hline Body products & Body lotion (7), Nail polish (1), Hand cream (1) & $5.8 \%(\mathrm{n}=9)$ \\
\hline $\begin{array}{l}\text { General hygiene } \\
\text { products }\end{array}$ & $\begin{array}{l}\text { Cleansing milk (13), Shower gel (8) Intimate hygiene (1), } \\
\text { Deodorant/antiperspirant (1), Perfume/eau de toilette (1) }\end{array}$ & $15.5 \%(\mathrm{n}=24)$ \\
\hline Hair care & Hair dye (6), Conditioner (1), Hairspray (1) & $5.2 \%(\mathrm{n}=8)$ \\
\hline Source: Authors & & \\
\hline
\end{tabular}

\section{Discussion}

The results of our study showed that when choosing cosmetics, women first of all take into account the function performed by the product, the price and the composition of the optional products. Some authors emphasize the name of a brand, followed by the quality and price of products (Cho et al., 2017). However, with other authors the first criterion of choice indicates the odor, followed by price and ingredients (Marie, 2016). The most commonly used products among Lithuanian women are hygiene products, including sweating products. Most researchers claim that the highest prevalence of cosmetics are hygiene products (Garcia-Hidalgo et al., 2017; Ficheux, et al., 2016; Park, 2015). A survey in Belgium indicated that $95 \%$ of young adults use deodorant or antiperspirant (Callewaert et al., 2014). The results of our study show that more than $87 \%$ of females use deodorant and/or antiperspirant and about $86 \%$ of them use perfume.

When comparing the prevalence and frequency of individual product use in different countries, there are some similarities. For instance, in Switzerland 75\% females reported using hair dyes, either applied by themselves or by someone else (Garcia-Hidalgo et al., 2017) meanwhile, our study showed hair dyes are used only by $63 \%$ Lithuanian females. There are some differences when comparing the prevalence of sunscreen use among the countries: about $20 \%$ of women have applied sunscreen in China (Yan et al., 2015), about $40 \%$ of American women regularly use sunscreen (Holman et al., 2015), more than $70 \%$ of French women use sun protection including sunscreens (Sassolas et al., 2015), and more than $90 \%$ of Korean women use sunscreen (Cho et al., 2017), while when it comes to Lithuanian women, less than $50 \%$ regularly use sunscreen.

The study in Lithuania showed that more that third part of respondents use 5-10 cosmetics per day. Some researchers have shown that the majority of respondents use 3 to 6 skin care products and 3 to 7 makeup products at a time (Cho et al., 2017). According to Ficheux et al. (2015) the females use 16 cosmetic products per day.

This study reveals that the prevalence and frequency of cosmetic use is different between separate age groups. Eye cream, sunscreen and some makeup products (lipstics, eye shadows) statistically significantly are most often used among women in the age group of 41 and older. Although older women use less cosmetics per day than younger ones. Whereas, in Koreans serum, milk lotion, nutrient cream, and eye cream use was proportionally increased in higher age groups (Cho et al., 2017). Older Swiss 
women use lipsticks, shampoo and conditioners less often than younger ones, but they use more often face and hand creams (Garcia-Hidalgo et al., 2017).

Our study revealed that a large number of respondents do not read product labels and do not ask a consultant about the composition of the product. The adverse effects of the cosmetic products can be prevented by reading expiry and manufacture date and by using cosmetic testers before committing to the use of new cosmetics. Study findings support the results of some previous research conducted with regard to cosmetics products. Most consumers purchase cosmetics without checking ingredients (Sniepiene \& Gerikiene, 2018; Cho et al., 2017; Besier, 2015). Not all women are familiar with the instructions and precautions before using the cosmetic products, and part of them do not read the instructions, but they still use the cosmetics comfortably (Massoro, 2016).

Manufacturers supply samples of products so they should be tested before the sale. However, our research revealed that a large number of respondents do not test cosmetics before using them. In addition, only a small part due to experiencing side effects referred to a physician after using cosmetics and performed patch tests. Certain cosmetics, especially hair colour product advertisements recommend the use of patch tests; using a small quantity of the new cosmetic on a small patch of hair or skin and observing for any reactions for a period of 48 hours before making greater use of the new cosmetic (Kim et al., 2016). The women who experienced contact dermatitis did not perform patch tests and re-used the same products (Zirwas, 2019).

Our study showed that most respondents, regardless of age, experienced side effects. When conducting the study, the respondents were asked whether there have been any adverse effects from cosmetics use. Assessing a lifetime period, the numbers are very high (about 80\%). Prior surveys also showed a high prevalence of adverse effects (83\%) among hair care product users in Lithuania, when assessing a lifetime period (Sniepiene \& Gerikiene, 2018). Other authors provide lower numbers (about 30-40\%), when assessing a shorter period of time (Shrestha and Shakya, 2016). According to Garcia-Hidalgo et al. (2017), 15\% of the females reported having experienced allergic skin reactions in the past year. According to our study the most common manifestations were as follows: skin irritation, itching, burning, and redness. Other authors report adverse reactions: skin irritation, allergic reactions and phototoxic reactions. However, the most common side effects were irritant and allergic contact dermatitis (Dornic, 2017; Nayak et al., 2017; Shrestha and Shakya, 2016; Zirwas, 2019). Our study shows that Lithuanian women with side effects statistically significantly use more fragrances, deodorants or antiperspirants compared to those who did not experience side effects. The most common products that caused side effects were makeup products: mascara, eye shadows and powders. Some researches show products that caused side effects were skin lightening cream, lipsticks, mascara and perfumes (Shrestha and Shakya, 2016). Other authors refer to mascara in this respect (Dartora et al., 2013; Zirwas, 2019).

The use of cosmetic products has a positive effect on self-expression and self-esteem by women, but it should be kept in mind that long-term use of some cosmetics, and in particular their ingredient combinations can also have a negative impact on consumer well-being, beauty and health. Nowadays, it would be difficult not to use absolutely any cosmetics, but some products, especially commonly used ones could be replaced with green/organic products (Chekima et al., 2016). Organic products do not contain chemical substances which may be hazardous to the body. There are no ingredients that damage the ecosystem, and their packaging is made of biodegradable or recyclable materials (Besier, 2015). Therefore, correct consumer habits, the safe and moderate use, and understanding the real impact of the products are very important. However, the findings of this study have shown that the use habits of cosmetic products pose a risk of adverse effects. The limitation of this study is that it is not possible to guarantee whether the products have been used for their intended purpose in accordance with the instructions.

\section{Conclusion}

The study shows that the choice criteria of cosmetic products differ among separate women age groups. The older women are more concerned about the composition of the products, their naturalness and the manufacturer, while the price is less important. Personal hygiene products including deodorants and perfumers are the most commonly used cosmetics. In addition, older women use less cosmetic products than younger ones. The majority of women have experienced side effects related to the use of cosmetics. 
The study shows that the occurrence of side effects does not depend on the number of products used. Instead, side effects are related to the use habits: e.g. women who experience side effects more often ( $\mathrm{p}$ $<0.05$ ) use expired cosmetic products. In addition, women with side effects are less likely to use cosmetic testers. It should be noted, that the consumers themselves have to take responsibility for their own safety. Cosmetics when used moderately and for their intended purpose and in accordance with the instructions for use and storage should not be hazardous to human health.

\section{References}

Ahaiwe, E.O., Onwumere J., \& Agodi, J.E. (2015). Analysis of Determinants of Brand Preference for Cosmetics in Abia State, Nigeria. The International Journal of Business \& Management, 3 (9): 244-250.

Batres, C., Kramer, S.S, De Angelis, C.G, \& Russell, R. (2019). Examining the 'cosmetics placebo effect'. PLoS ONE 14(1): e0210238. https://doi.org/10.1371/journal.pone.0210238

Bernard, A., Houssin, A., Ficheux, A.S., Wesolek, N., Nedelec, A.S, Bourgeois, P., Hornez, N., Batardiere, A., Misery, L., \& Roudot A.C. (2016). Consumption of hair dye products by the French women population: Usage pattern and exposure assessment. Food and Chemical Toxicology, 88, 123-132. https://doi.org/10.1016/j.fct.2016.01.002

Bondi, C.A.M., Marks, J.L., Wroblewski, L.B., Raatikainen H.S., Lenox, S.R., \& Gebhardt, K.E. (2016). Human and Environmental Toxicity of Sodium Lauryl Sulfate (SLS): Evidence for Safe Use in Household Cleaning Products. Environ Health Insights, 9, 27-32. https://doi.org/10.4137/EHI.S31765

Besier, S. (2015). Generational perceptions of pro-environmental packaging advantages. Schwerpunktthema, 23, 315-322. https://doi.org/ 10.1007/s00550-015-0375-2

Callewaert, C., Hutapea, P., Van de Wiele, T., \& Boon, N. (2014). Deodorants and antiperspirants affect the axillary bacterial community. Arch Dermatol Res. 306, 701-710. https://doi.org/10.1007/s00403-014-1487-1

Chekima, B, Wafa, S.A, Aisat Igau, O., Chekima, S, \& Sondoh, S.L. (2016). Examining green consumerism motivational drivers: does premium price and demographics matter to green purchasing? Journal of Cleaner Production, 112 (4) 20: 34363450. https://doi.org/10.1016/j.jclepro.2015.09.102

Cho, S., Oh, S., Kim, N.I., Ro, Y.S, Kim, J.S, Park, Y.M., Park, C.W., Lee, W.J, Kim, D.K., Lee, D.W., \& Lee, S.J. (2017). Knowledge and Behavior Regarding Cosmetics in Koreans Visiting Dermatology Clinics. Ann Dermatol., 29(2): 180-186. https://doi.org/10.5021/ad.2017.29.2.180

Comiskey, D., Api, A.M., Barratt, C., Daly, C.J., Ellis, G., McNamara, C., O’Mahony, C., Robison, S.H., Safford, B, Smith, B., \& Tozer, S. (2015). Novel database for exposure to fragrance ingredients in cosmetics and personal care products. Regulatory Toxicology and Pharmacology, 72, 660-672. http://dx.doi.org/10.1016/j.yrtph.2015.05.012

Commission, E., 2009. Regulation (EC) No. 1223/2009 of the European Parliament and of the Council. Off. J. Eur. Union 1223, 342/59-208.

Dartora, G., Dienfethaeler, H.S, \& Haas, S.E. (2013). Investigation on the use of expired make-up and microbiological contamination of mascaras. International journal of cosmetic science, 35(4): 375-80. https://doi.org/10.1111/ics.12053

Dornic, N., Ficheux, A.S., \& Roudot, A.C. (2017). Consumption of cosmetic products by the French population. Third part: Product exposure amount. Food and Chemical Toxicology 106, 209-222. http://dx.doi.org/10.1016/j.fct.2017.05.049

Ficheux, A.S., Bernard, A., Chevillotte, G., Dornic, N., \& Roudot, A.C. (2016). Probabilistic assessment of exposure to hair cosmetic products by the French population. Food and Chemical Toxicology, 92, 205-216.

https://doi.org/10.1016/j.fct.2016.04.009

Ficheux, A.S., Wesolek, N., Chevillotte, G., \& Roudot, A.C. (2015). Consumption of cosmetic products by the French population. First part: Frequency data. Food and Chemical Toxicology, 78, 159-169.

http://dx.doi.org/10.1016/j.fct.2015.01.016

Fotouhi, M., Seidi, S., Shanehsaz, M., \& Naseri, M.T. (2017). Magnetically assisted matrix solid phase dispersion for extraction of parabens from breast milks. Journal of Chromatography A, 1504, 17-26.

https://doi.org/10.1016/j.chroma.2017.05.009

Garcia-Hidalgo, E., von Goetz, N., Siegrist, M., \& Hungerbühler, K. (2017). Use-patterns of personal care and household cleaning products in Switzerland. Food and Chemical Toxicology, 99, 24-39. https://doi.org/10.1016/j.fct.2016.10.030

Geer, L.A, Pycke, B.F.G., Waxenbauma, J., Sherer, D. M., Abulafia, O., \& Haldenb, R.U. (2017). Association of birth outcomes with fetal exposure to parabens, triclosan and triclocarban in an immigrant population in Brooklyn, New York. Journal of Hazardous Materials, 323, 177-183. https://doi.org/10.1016/j.jhazmat.2016.03.028

Giulivo, M., Lopez de Alda, M., Capri, E., \& Barceló, D. (2016). Human exposure to endocrine disrupting compounds: Their role in reproductive systems, metabolic syndrome and breast cancer. A review. Environmental Research 151, 251-264. https://doi.org/10.1016/j.envres.2016.07.011

Holman, D.M., Berkowitz, Z., Guy, G.P., Hawkins, N.A., Saraiya, M., \& Watson, M. (2015). Patterns of Sunscreen Use on the Face and Other Exposed Skin among US Adults. J Am Acad Dermatol., 73 (1): 83-92.

http://dx. doi:10.1016/j.jaad.2015.02.1112

Jurewicz, J., Radwan, M., Wielgomas, B., Klimowska, A., Kałużny, P., Radwan, P., Jakubowski, L., \& Hanke, W. (2017). Environmental exposure to parabens and sperm chromosome disomy. International Journal of Environmental Health Research, 27(5), 332-343. https://doi.org/10.1080/09603123.2017.1339784 
Kim, K.H., Kabir, E., \& Jahan, S.A. (2016). The use of personal hair dye and its implications for human health. Environment International, 89-90, 222-227. http://dx.doi.org/10.1016/j.envint.2016.01.018

Kirchhof, M.G, \& de Gannes, G.C. (2013). The health controversies of parabens. Skin Therapy Lett., 18, 5-7.

Lu, S., Wang, N., Ma, S., Hu, X., Kang, L., \& Yu, Y. (2019). Parabens and triclosan in shellfish from Shenzhen coastal waters: Bioindication of pollution and human health risks. Environmental Pollution, 246, 257-263. https://doi.org/10.1016/j.envpol.2018.12.002

Malinauskiene, L., Blaziene, A., Chomiciene, A., \& Isaksson, M. (2015). Formaldehyde may be found in cosmetic products even when unlabeled. Open Med., 10, 323-328. https://doi.org/10.1515/med-2015-0047.

Marie, C., Cabut, S., Vendittelli, F., \& Sauvant-Rochat M.P. (2016). Changes in Cosmetics Use during Pregnancy and Risk Perception by Women. Int J Environ Res Public Health, 13(4): 383. https://doi.org/10.3390/ijerph13040383

Massoro, Z.Z. (2016). Information Seeking and Use Behaviour on Beautification Product among Students of Higher Learning Institutions. Middle-East Journal of Scientific Research, 24(1): 149-156. https://doi.org/ 10.5829/idosi.mejsr.2016.24.01.22367

Morgan, M., Deoraj, A., Felty, Q., \& Roy, D. (2017). Environmental estrogen-like endocrine disrupting chemicals and breast cancer. Molecular and Cellular Endocrinology, 457, 89-102. https://doi.org/ 10.1016/j.mce.2016.10.003.

Nayak B.S, Ann, C.Y., Azhar A.B., Ling E.C., Yen, W.H., \& Aithal, P.A. (2017). A Study on Scalp Hair Health and Hair Care Practices among Malaysian Medical Students. Int J Trichology, 9(2): 58-62. Int J Trichology, 9(2): 58-62. https:// doi.org/10.4103/ijt.ijt_76_16 DOI: 10.4103/ijt.ijt_76_16

Nowaka, P.K., Ratajczak-Wronaa, W., Górskab, M., \& Jabłońskaa, E. (2018). Parabens and their effects on the endocrine system. Molecular and Cellular Endocrinology, 474, 238-251. https://doi.org/10.1016/j.mce.2018.03.014

Park, J.Y., Lee, K., Hwang, Y., \& Kim, J.H. (2015). Determining the exposure factors of personal and home care products for exposure assessment. Food and Chemical Toxicology, 77, 105-110. https://doi.org/10.1016/j.fct.2015.01.002

Sassolas, B., Grange, F., Touboul, C., Lebbe, C., Saiag, P., Mortier, L., Lhomel C., \& Robert, C. (2015). Sun exposure profile in the French population. Results of the EDIFICE Melanoma survey. JEADV, 29 (2): 6-10. https://doi.org/ $10.1111 / j \mathrm{jv} .12895$

Shrestha, R., \& Shakya, J. (2016). Knowledge regarding adverse effects of selected cosmetic products among higher secondary level girl students, Chitwan. Journal of Chitwan Medical College, 6(16): 27-32. https://doi.org/10.3126/jcmc.v6i2.16685

Sniepiene, G., \& Gerikiene, V. (2018). Health adverse effects of Hair care: expression, selection criteria, education. Sveikatos mokslai / Health Sciences in Eastern Europe, 28(3): 5-10.https://doi.org/10.5200/sm-hs.2018.032

Vainauskiene V., \& Vaitkiene R. (2014). Foresight of brand vulnerability: the case of the Lithuanian market of cosmetic products. Procedia - Social and Behavioral Sciences, 156, 501- 505. https://doi.org/10.1016/j.sbspro.2014.11.229

Vela-Soriaa, F., Gallardo-Torres, M.E., Ballesteros, O., Díazc, C., Pérezc, J., Navalónb, A., Fernández, M.F., \& Oleaa, N. (2017). Assessment of parabens and ultraviolet filters in human placenta tissue by ultrasound-assisted extraction and ultrahigh performance liquid chromatography-tandem mass spectrometry. Journal of Chromatography A, 1487, 153-161. https://doi.org/10.1016/j.chroma.2017.01.041

Wu, P.T., \& Lee, C.J. (2016). Impulse buying behaviour in cosmetics marketing activities. Total Quality Management \& Business Excellence, 27 (10): 1091-1111. https://doi.org/10.1080/14783363.2015.1060851

Zhaoa, H., Lia, J., Maa, X., Huob, W., Xub, S., \& Caia, Z. (2018). Simultaneous determination of bisphenols, benzophenones and parabens in human urine by using UHPLC-TQMS Chinese Chemical Letters, 29, 102-106.

https://doi.org/10.1016/j.cclet.2017.06.013

Yamaguchi, M., Araki, D., Kanamori, T., Okiyama, Y., Seto, H., Uda, M., Usami, M., Yamamoto, Y., Masunaga, T., \& Sasa, H. (2017). Actual consumption amount of personal care products reflecting Japanese cosmetic habits. The Journal of Toxicological Sciences (J. Toxicol. Sci.), 42 (6): 797-814. https://doi.org/10.2131/jts.42.797

Yan, S., Xu, F., Yang, C., Li, F., Fan, J., Wang, L., Cai, M., Zhu, J., Kan, H., \& Xu, J. (2015). Demographic Differences in Sun Protection Beliefs and Behavior: A Community-Based Study in Shanghai, China. Int. J. Environ. Res. Public Health, 12, 3232-3245. https://doi.org/10.3390/ijerph120303232

Zirwas, M.J. (2019). Contact Dermatitis to Cosmetics. Clinical Reviews in Allergy \& Immunology, 56, 119-128. https://doi.org/10.1007/s12016-018-8717-9 